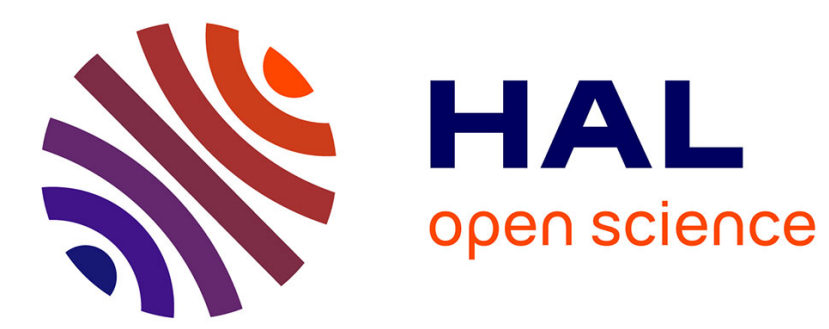

\title{
Reform of Higher Legal Education: Global Issues
}

Anatoliy Kostruba

\section{To cite this version:}

Anatoliy Kostruba. Reform of Higher Legal Education: Global Issues. 2021, pp.1-3. hal-03350162

\section{HAL Id: hal-03350162 \\ https://hal.science/hal-03350162}

Submitted on 21 Sep 2021

HAL is a multi-disciplinary open access archive for the deposit and dissemination of scientific research documents, whether they are published or not. The documents may come from teaching and research institutions in France or abroad, or from public or private research centers.
L'archive ouverte pluridisciplinaire HAL, est destinée au dépôt et à la diffusion de documents scientifiques de niveau recherche, publiés ou non, émanant des établissements d'enseignement et de recherche français ou étrangers, des laboratoires publics ou privés. 


\section{VOLUME 1.1 | Issue 1| Jan - Jun , 2021}

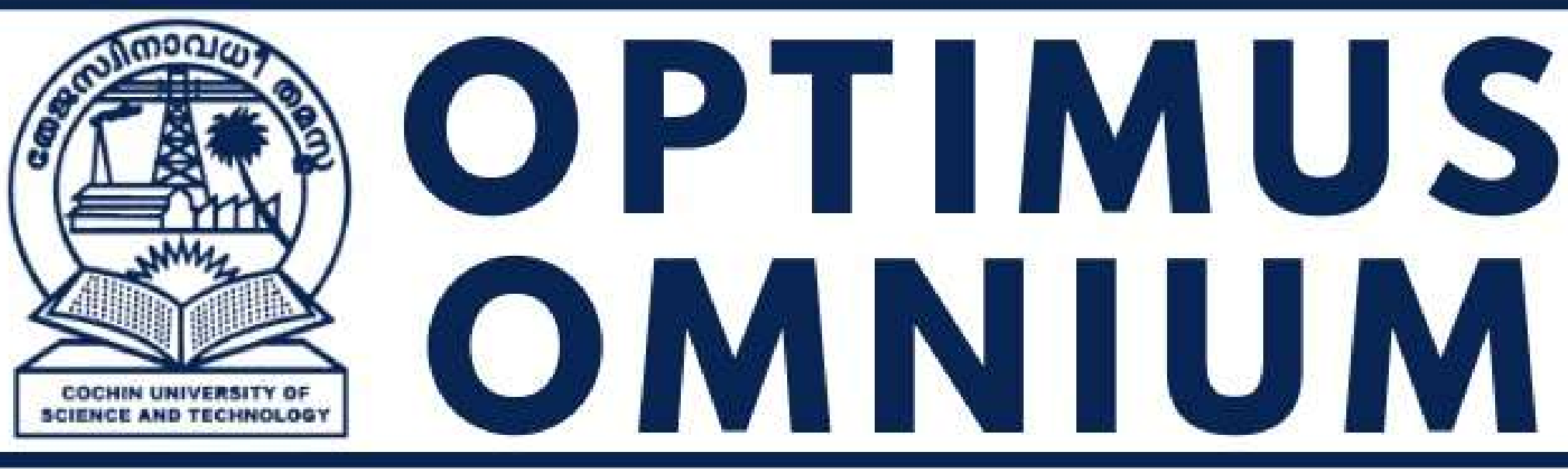

\section{SLS NEWS LETTER}
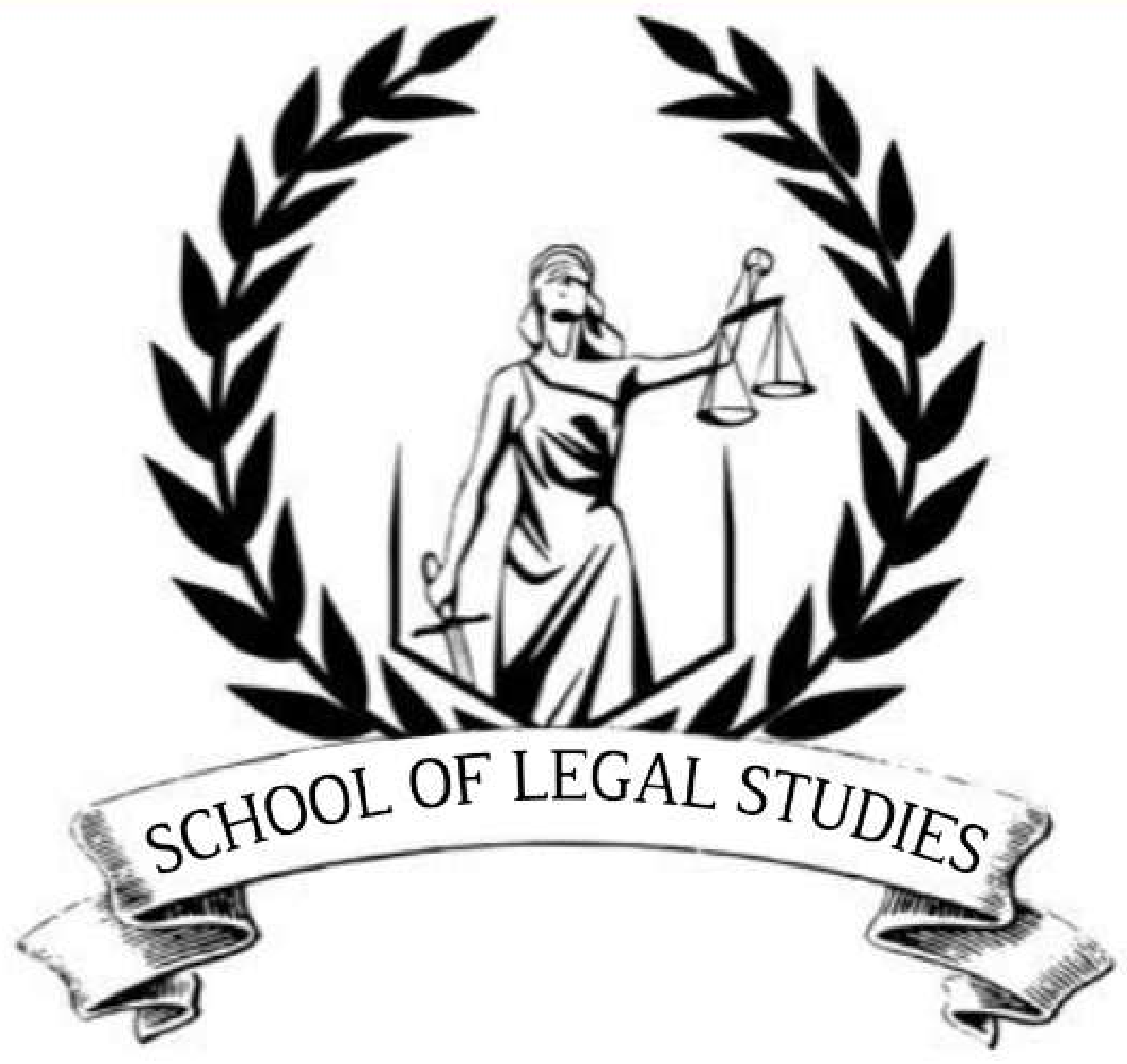

COCHIN UNIVERSITY OF SCIENCE AND TECHNOLOGY KOCH I, K E R A L A 


\section{Editor's Note}

School of Legal Studies is one of those departments in the Cochin University of Science and Technology, where programmes are conducted qualitatively as well as quantitatively. We conduct wide range of programmes which include outreach programmes, interdisciplinary programmes, webinars, seminars, Faculty Development Programmes, Workshops, public awareness classes and other programmes involving the public. The dignitaries that have added colors and fragrance to these programmes are nationally and international reputed personalities, including our own alumni. As a student friendly department, we take pride and pleasure in all the achievements of our students in-house and otherwise, academic and extracurricular. Our students come with flying colors in almost all events they take part. The members of faculty add margin to every filed of their academic persuasion by organizing wide range of programmes, taking part in various national and international programmes, by publishing articles and books, as well as and by creating an excellent generation of students with wider visions, commitments and integrity. The members of our staff also excel in their own fields.

These activities and achievements find a comprehensive space in our Newsletter- Optimum Omnium. This is a reflection of the overwhelming enthusiasm of all echelons in the School of Legal Studies. We thank all those supported us in this endeavor- the Director of the School of Legal Studies, who gave us all the liberty and support, the members of faculty who extended all their encouragements, and contributions, to all the authors who shared their esteemed thoughts with us for further thinking for all, the members of Alumni Association who are constant supports to us in all our endeavors, the students who are always the soul and heart of the School and all the members of the staff who are the inevitable part of all activities of the School. We hope that this humble initiative from the School will go a long way in creating healthy debates of recent legal and other issues, and in inspiring all to do more and more things in their own unique way in future which can break new paths in legal education.

Dr. P. S. Seema

Dr. Aneesh V. Pillai 


\section{Director's Message}

This newsletter is a product of concerted effort of the members of faculty, students and staff of the SLS family which conveys the message that "everyone is a leader" in her or his own humble ways. The year 2020 has been an year of challenge for all human lives in general, however a cursory glance of this newsletter will give one an insight as to the different ways in which this law school has contributed to the academic world as well as the society in its avowed objective of transforming and translating knowledge for the benefit of ordinary lives. It throws a brief light on the various activities undertaken by the law school including International and national webinars, moot court competitions, quiz, debates, arts fests, sports etc. in which both the faculty and students have conducted, participated as well as won many accolades. I take this opportunity to congratulate the faculty in charge for their earnest endeavor in bringing forth this newsletter. I hope and wish that this newsletter would provide us as well as those in the field of legal education necessary impetus to bring novel initiatives so that we evolve a global citizenry for the future who respect the fundamental notions of Law and justice.

Dr. Vani Kesari A.

Director

School of Legal Studies

Cochin University of Science and Technology 


\section{Guest Article}

\section{Reform of Higher Legal Education: Global Issues}

\section{Kostruba Anatolii Volodymyrovych}

Doctor of Law, Professor of the Civil Law Department

Vasyl Stefanyk Precarpathian National University

Ivano-Frankivsk city, Ukraine

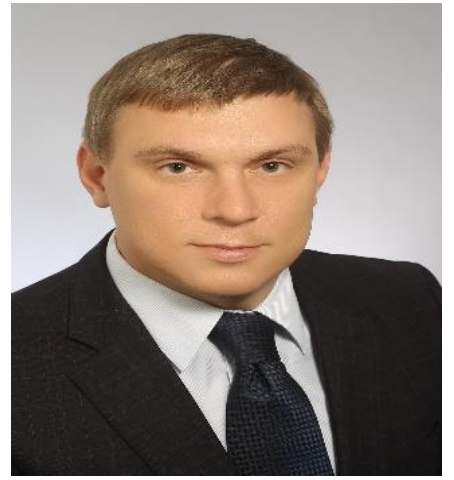

The main vector of higher legal education development is determined by the general direction of the domestic higher school to join the all-European and world educational space, national and international standards harmonization of higher education in the context of the Bologna process. On the other hand, the rapid development of information technologies has led to the global computerization of society. The result of this phenomenon in the education field is a stable environment formation of developed data processing, information systems modular construction (combination of different architectural types within a single complex). As a result, knowledge building process for skills formation of professional competence is gradually changing the form of its realization. The wellknown learning goals of higher school revealed in such elements as knowledge, understanding and forms of their acquisition are changing. It is no coincidence that the problem for most universities is the fact that education is still more focused on knowledge and skills, rather than on personality development, consciousness formation and self-awareness of a specialist.

Unfortunately, such changes do not always have a positive educational trajectory. It should be recognized that educational institutions are no longer the major educational source. Those basic learning goals, the achievement of which is the task of higher school, do not receive appropriate positive reflection in society. High level of knowledge with no skills of its application is the main factor of professional deformation of a graduating student of higher educational institution. This problem is clearly visible in the higher legal education sphere. In recent times, there has been a clear trend toward the transition from qualification to the competence-based model of the specialist. The emphasis in professional training is shifting to socio-personal and general professional competencies. Open 
statistical sources of the State Employment Service show that among the total number of unemployed persons with higher education who could not find the first job, persons with higher legal education occupy one of the leading places (26\%).

In early 2019, the Ministry of Justice of Ukraine together with the Ministry of Education and Science of Ukraine proposed a draft Concept of the Legal Education Reform for public discussion. Among the main problems were a mismatch between the content of legal education and training quality in legal schools with the modern requirements of the labour market and the challenges facing the modern democratic society, global trends in development and tasks of employees' professional activities in various fields. The abovementioned requires a change in the educational paradigm, one of the components of which, in our opinion, should be the transition to educational goals of a different qualitative type in the cognitive sphere, including the formation of applied professional legal skills, critical thinking development and so on. Unfortunately, there is not enough scientific research in this area of narrow thematic nature. No significant attention is paid to the pedagogical problems of lawyers' model formation with their readiness for social interaction.

It is important to emphasize that among legal scholars there is no interest in the development and formation of legal pedagogy as a direction in pedagogy of higher education, the subject of which is the didactic peculiarities of the professional competence formation of lawyers. Part of the attention is paid to the professional competence formation among students of higher educational institutions in the legal field by scholars of pedagogical science, in particular, the theory and methods of training and education (according to the fields and educational level). The problem to be solved is the mismatch between the content of legal education and training quality in legal schools with the modern requirements of the labour market and the challenges facing the modern democratic society, global trends in development and tasks of employees' professional activities in various fields, this is due to the insufficient level of theoretical knowledge and practical skills among a significant part of graduating students of law schools, as well as a lack of attention to the formation of a holistic world view among applicants for legal education with an understanding of the social mission, values and importance of legal profession to approve the rule of law in the modern democratic society. 
The abovementioned requires the updating of educational processes modernization issue in the direction of competency-oriented training formation and professional lawyer education in the light of his/her dialogue and discussion, and language-intensive professional activities. In particular, it is important to develop an approach to the professional training of a future lawyer, which involves the creation of a professional competence formation model of the lawyer, which is based on the organic unity of theoretical, practical, psychophysical training that will provide the professional socialization level engaging a wide range of scholars in the field of pedagogy and law.

\section{Guest Article}

\section{Prisoners' Right to Health Care}

\section{Prof. (Dr.) N. S. Soman}

Former Director \& Dean

School of Legal Studies

Cochin University of Science and Technology, Kerala

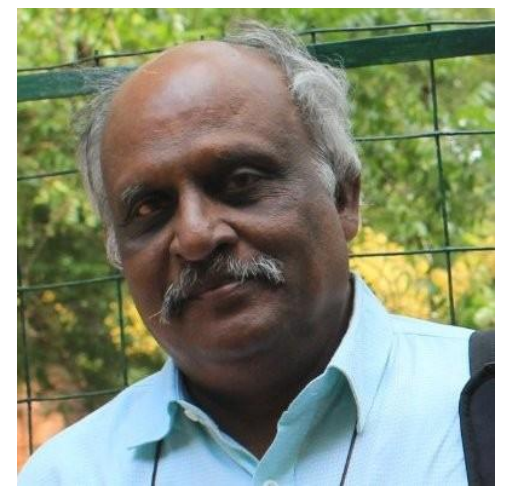

A convict sentenced by competent court is a persona non grata and dumped inside the prison to be forgotten by the law and legal system. Law is of no help to him since he is "civilly dead". His status as state slave and a person met with "civil death" disentitles him of any assistance from the law courts in case of any injury done towards him. The courts take a "hands off" stand, which is a corollary stand based on the doctrine of "civil death". New developments in penology as well as the concept of rights of individuals created inroads into this traditional stand of courts. It is insisted that the public being responsible for deprivation of the liberty of the convict, indisputably it is under an obligation to take care of the prisoner, since he could not do it himself. Such an obligation would enable the prisoners to lead a dignified life. The prisoner, the state slave, now stands emancipated and no longer neglected to receive only the rights granted at the whims of prison authorities. Courts abandoned "hands-off" doctrine and no longer reject prisoner's complaints about legal wrongs as necessary conditions of imprisonment. New constitutional interpretations never allowed the writs to stop at the prison gate. 